\title{
Paralympijský sport jako společenský fenomén
}

\author{
Paralympic sport as a social phenomenon
}

\author{
Tomáš Zelenka, Martin Kudláček
}

\author{
Fakulta tělesné kultury Univerzity Palackého v Olomouci
}

\begin{abstract}
Abstrakt
Sport osob se zdravotním postižením začal být v současné době chápán jako reálně existující, rychle a pritom zcela přirozeně se rozvijející fenomén. Tento fakt je po celém světě dokumentován řadou důkazů. Jedním z nich je současné postavení a popularita Paralympijských her. Potvrzuje to také dynamický nárůst počtu hendikepovaných sportovců, rostoucí nabídka aplikovaných sportů, sportovních programů a různých sportovních soutěží. Paralelnè dochází i k rozvoji relevantních národních a mezinárodních organizací a institucí. V některých případech lze fenomén dokumentovat i propojením či splynutím sportovních platforem zdravých sportovců a sportovců s postižením. Vjedné rovině se sport $v$ kontextu sportovců se zdravotním postižením stal extraverzním nástrojem ukázky jejich atletických schopností. $V$ druhé rovině pak intraverzním prostredkem majícím bezesporu pozitivní vliv na biologickou, psychologickou a sociologickou podstatu člověka. Bohužel zapojení osob se zdravotním postižením do sportovních aktivit je na velmi nízké úrovni.
\end{abstract}

\begin{abstract}
Sport for persons is promptly and naturally evolving as social phenomenon. This fact is documented worldwide variety of evidence. It is not only about the status and popularity of the Paralympic Games, it is not only dynamically growing number of disabled athletes and the growing range of adaptive sports, sports programs and various levels of competitions, but side by side with it the development of relevant national and international organizations and institutions, and even in some cases linking or merging sports platforms of ablebodied and handicapped athletes. Sport in the context of disabled athletes become parallely extroverted device demonstrations of their athletic abilities and also introverted medium having a positive influence on the biological, psychological and sociological human nature. On the other hand disabled people sport activity involvement is unfortunately very low.
\end{abstract}

\section{Klíčová slova}

sport osob se zdravotním postižením, bariéry, facilitátory, participace, medializace, trenéři

\section{Key words}

disability sport, disability athletes, barriers, facilitators, participation, media coverage, coaches

Tento přispěvek vzniklv rámci řešení projektu:IGA_FTK_2015_007 Pohybová aktivita a životnístyl jako determinanty zdravi a kvality života osob se zdravotním postižením.

Ačkoli je skutečnost komplexního přínosu pohybových aktivit pro osoby se zdravotním postižením prokázána, at' už se jedná o soutěžní nebo jinou formu, je míra zapojení této specifické skupiny osob do těchto programů bohužel stále velmi nízká, obzvláště v komparaci s účastí zbývající části populace (Kawanishi \& Greguol, 2013). Významně nižší hodnoty sportovní participace u osob se zdravotním postižením způsobují faktory, které jsou specifické pro tuto část populace. Odborníci i zdravotní organizace zabývající se touto problematikou uvádějí bariéry na straně jedné a facilitátory na straně druhé (Meyers et al., 2002; Rimmer et al., 2004; WHO, 2011). V praxi jde víceméně o totéž, bezbariérový př́istup do sportovních zařízení může být pro ilustraci problematiky facilitátorem, naopak absence vhodného př́stupu je považována za formu bariéry. 
V kontextu osob se zdravotním postižením je zajímavé, že hendikep dle Mezinárodní klasifikace funkčních schopností, disability a zdraví vzniká, když se občan se svým zdravotním stavem setkává $\mathrm{s}$ bariérami prostředí. Zjednodušeně můžeme říci, že jde o spolupůsobící faktory, reprezentované osobními faktory na straně jedné a faktory prostředí na straně druhé. V kontextu sportovní participace osob se zdravotním postižením pak přeneseně mohou bariéry zejména vznikat, pokud se jedinec neztotožní s rolí sportovce nebo když prostředí komplikuje podmínky pro sport. V teoretické rovině se potom lze domnívat, že hendikep alias bariéry, bud' nemusí nic znamenat, nebo v lepším případě nemusí vůbec existovat. V prvním prŕpadě se tak může stát za situace, kdy se osobám se zdravotním postižením podaří osvojit si specifickou sportovní identitu, která napomáhá vypořádat se s bariérami sportovního prostředí. $V$ druhém př́padě musí dojít k pozitivním změnám v postojích většinové společnosti vůči osobám se zdravotním postižením, která bariéry sportovního prostř̌edí vytváŕí. Za jeden z názorných př́kladů bariér lze např́klad považovat i absenci trenéra, který může sehrát důležitou roli u sportovce se zdravotním postižením a sportu zároveň. Svou komplexní rolí může pozitivně působit na výkonnost sportovního jedince a souběžně pozitivně ovlivňovat podmínky sportovního prostředí.

V obecné rovině je nutné dodat jednu důležitou skutečnost. Vzhledem k prokázaným benefitům sportovních aktivit u osob se zdravotním postižením dochází pravděpodobně v rámci aktivního životního stylu k jejich daleko většímu významu, než je tomu u ostatní populace (van der Ploeg et al., 2004). Většina takto zaměřených studií ale vzápětí dodává potřebu dalších informací k potvrzení těchto úvah a především $\mathrm{k}$ dalšímu porozumění tohoto jedinečného prostředí, nejenom v úzkém, ale zejména i v širším kontextu.

Téměř před 30 lety publikovala K. P. DePauw (1986) studii s názvem Research on Sport for Athletes With Disabilities, ve které již v samotném úvodu popisuje zásadní změnu v paradigmatu sportu osob se zdravotním postižením. Sportovní orientace osob se zdravotním postižením se přirozeným způsobem přemístila z rehabilitační oblasti do zóny soutěžního charakteru, čímž se sport stal obrovskou př́ležitostí k názorné ukázce jejich atletických schopností. Sportovec se zdravotním postižením získal tímto aktem reálnou možnost následovat a sdílet stejné životní hodnoty jako zdravý sportovec. Samozřejmě za předpokladu, že sport poslouží jako médium pro rozvoj společensky žádoucích postojů a chování, což přispěje k plnohodnotnému využití možností v kontextu osobního zdraví (Clark, 1986). V souvislosti s nástupem fenoménu sportu, v kontextu sportovců se zdravotním postižením, bylo kompetentními subjekty identifikováno sedm prioritně výzkumných oblastí, které měly sloužit nejenom jako nástroj k získání povědomí a $\mathrm{k}$ určitému porozumění, ale zároveň měly být počátkem potřebných změn tohoto specifického sportovního prostředí (DePauw, 1986). Předmětem budoucího výzkumu se měly stát tyto tématicky rozdělené okruhy: (a) dopad trénování a soutěžení v kontextu všeobecného zdraví, (b) technologický vývoj, (c) sociologické a psychologické aspekty sportu, (d) rozdílné a shodné prvky sportu zdravých a hendikepovaných, (e) demografická struktura sportu, (f) filosofie, historie a legalita sportu a $(\mathrm{g})$ personální oblast v podobě dobrovolníků, funkcionářu a trenérů.

Navzdory historicky vytyčeným výzkumným cílům je současný stav vypovídajících informací odborníky hodnocen jako kvantitativně nedostatečný, speciálně pak v souvislosti se zaměřením na oblast trénování sportovců se zdravotním postižením (Banack et al., 2011; Hanrahan, 2007; McMaster et al., 2012; Tawse et al., 2012). Jako nesporný důkaz lze uvést přehledovou studii s překvapivými výsledky, zahrnující komparaci dvou vybraných dekád výzkumu v rozmezí let 1986-96 a 2001-11. Výsledky ukazovaly nejenom snížení celkového počtu provedených výzkumných studií a systematických přehledů v kontextu sportu a postižení, ale celkem logicky i snížení relativní četnosti relevantních výzkumných studií a systematických přehledů obsahující kategorii výběru a vzdělávání trenérů (Lee \& Poretta, 2013). Stejná studie uvedla i trendy v oblasti výzkumu, nárůst zájmu byl shledán u sofistikovanějších kategorií fyziologie a biomechaniky. Na základě těchto skutečností lze konstatovat, s ohledem na současný stav a rozvoj adaptivních sportů, že jsou některé historicky problematické oblasti i nadále aktuální. Vzhledem k rozvoji této oblasti se přirozeně v kontextu potřebného výkumu objevila témata nová.

Počet deklarovaných výzkumých studií v personální oblasti nelze přejít bez povšimnutí. Jedná se o oblast a zároveň o zdroj zaměřený na lidský kapitál, který je spolu s věcnými vstupy důležitým 
prvkem potřebného rozvoje. Lidské zdroje jsou tvůrčí, vytvářejí podmínky a uvádějí svou činností do pohybu ostatní zdroje, ohraničují limity dané oblasti a určují její efektivitu. Ve sportovním kontextu se nejedná o nic jiného než o lidský faktor, zejména v podobě trenérů, dále pak dobrovolníků, funkcionářů a rozhodčích, jakožto hlavních opor a stabilizačních prvků struktury sportu se zdravotním postižením. V této souvislosti je lidský faktor v kontextu sportu osob se zdravotním postižením předmětem mnoha diskusí, zejména pokud jde o trenérskou základnu nebo strukturu sportů, jako důležitých nástrojů rozvoje sportu. Jsou to dle výzkumů právě trenéři, kteří disponují velkým vlivem nejenom na sportovce, ale zároveň i na zmiňovanou sportovní infrastrukturu.

Nedávný výzkum prokázal, že problematika trenérství se stále objevuje v konkrétní podobě a to zejména $\mathrm{v}$ nedostatku erudovaných trenérů, působících $\mathrm{v}$ oblasti sportu se zdravotním postižením (Robbins et al., 2010). Ve stejném duchu se přidává další př́spěvek, který reflektuje současnou nedostatečnou trenérskou základnu a strukturu paralympijských sportů (Sawicki, 2008). V daný moment paralympijský sport naráží na své limity, nebot' prostřednictvím kvalitních trenérů přichází o důležitý nástroj rozvoje nejenom samotných trenérů, potažmo paralympijských sportovců, ale dokonce i paralympijského sportu jako takového. Lze zdokumentovat i opačný př́stup ve formě pozitivního a zároveň pokrokového řešení trenérské problematiky v praxi. Názorným př́kladem může být př́stup kanadských paralympijských plavců k nejlepším trenérům v oboru, respektive ke stejné úrovni trenérských schopností, kterými disponuje zdravý úsek sportovců (Martin, 2015). Právě tato alternativa je předmětem diskusí některých trenérů. Spojení zdravých sportovců a sportovců se zdravotním postižením je názorným př́kladem poslední dobou skloňované inkluze, která vidí př́ínos v obohacení všech zainteresovaných stran (Sawicki, 2008). Problematika trenérství není samozřejmě černobílá, nicméně studie z této oblasti předpokládají (Wilson \& Khoo, 2013) a zároveň potvrzují (Crawford \& Stodolska, 2008), že státy s omezenými finančními zdroji budou v oblasti trenérství čelit složitějším výzvám.

\section{Problematika trénování sportovců se zdravotním postižením}

Institut trénování je z pohledu funkce nesmírně složitý soubor předávání zkušeností a dovedností. Trénování se netýká pouze trenérů a sportovců. Do styku s trénováním denně přicházejí například také rodiče, fyzioterapeuti a v neposlední řadě i zdravotnický personál. $\mathrm{V}$ rámci své profese trenéři vstupují do nesčetného množství rolí, včetně teorie a výuky praktických dovedností, jako je schopnost vést, umění týmové práce formování charakteru svých sportovců. Trenéři pak na nejvyšším stupni vytvářejí prostředí, kde jsou dovednosti a hodnoty nabyté sportem, prezentovány nejenom na sportovištích, ale i v běžné společnosti. Symbióza vztahu trenéra a sportovce je dokáže ještě umocnit. V obou zmiňovaných rovinách může být role trenérů obzvláště cenná, jedná-li se o sportovce se zdravotním postižením (Tawse et al., 2012).

V obecné rovině se sumarizuje fakt, že je důležité uvědomit si některé klíčové faktory, které v rámci trénování sportovců se zdravotním postižením do procesu vstupují a jsou pro tuto oblast specifické (Turnnidge et al., 2014). Ačkoli trénování sportovců se zdravotním postižením vyžaduje mnoho stejných dovedností jako u zdravých sportovců, mohou se vyskytnout faktory, kterými se oblast trénování sportovců se zdravotním postižením stává unikátním, a ke kterým se v rámci trenérských aktivit musí jednoznačně přihlížet (Cregan et al., 2007). Trénování sportovců obecně vyžaduje základní dovednosti, jako je např́íklad poskytování vhodné zpětné vazby, stanovení realistických cílů, rozvoj dovedností a strukturování pravidelného tréninkového objemu (Horn, 2008). V prípadě trénování sportovců se zdravotním postižením je kromě těchto základních dovedností požadován i nadstandard v podobě plánování a znalostí v kontextu specifik, které mohou souviset např́íklad s prístupností relevantních sportovních zařízení, logistikou, různými druhy zdravotního postižení nebo samotnou funkční nezávislostí sportovce se zdravotním postižením (Banack et al., 2011; Cregan et al., 2007; McMaster et al., 2012; Tawse et al., 2012). Trenéři by měli v kontextu uvedených specifik sportovců se zdravotním postižením disponovat snahou pochopit povahu zdravotního postižení, doprovázenou potřebnými znalostmi v oblasti biomechanických úprav (DePauw \& Gavron, 2005). 
Trenéři by navíc měli být kreativní při navrhování struktury tréninkových jednotek, aby vyhovovaly specifickým potřebám každého sportovce, respektive zohledňovaly úroveň jednotlivých dovedností nebo úroveň jejich sportovní zainteresovanosti (Cregan et al., 2007).

Vzhledem k výše uvedeným informacím lze identifikovat jednoznačnou a plošnou shodu v tom, že trenéři musí primárně disponovat komplexními znalostmi o stavu sportovce v souvislosti s jeho zdravotním postižením. Nejde pouze o jeho diagnózu a zdravotní omezení, ale zejména o specifické okolnosti v širším kontextu s jeho zdravotním stavem a běžným nebo sportovním fungováním. Klíčovým faktem je především nedostatek zkušeností v kontextu zdravotního postižení, nebot' těmito specifickými znalostmi nemůže většina běžných trenérů primárně disponovat. V této oblasti je pravděpodobně nelze získat jinak, než učením nebo praxí (Martin \& Whalen, 2015). Je tedy celkem jasné, že jakoukoliv formou získané zkušenosti ve sportu osob se zdravotním postižením jsou předpokladem určité trenérské hodnoty (Martin \& Whalen, 2015). Pokud touto hodnotou trenér nedisponuje, nemusí být jeho práce pozitivně vnímána. Konkrétním př́padem jsou názory sledge hokejistů, kteř́ byli přesvědčeni o tom, že pokud by jejich trenér disponoval vlastními zkušenostmi v oblasti sledge hokeje, jeho práce by byla více efektivní a vnímána více pozitivněji (Wynnyk \& Spencer-Cavaliere, 2013). Na základě těchto empirických dat se logicky nabízí myšlenka, že nejlepšími trenéry mohou být jen ti, kteří sami disponují zdravotním postižením a zároveň mají vlastní zkušenosti s rolí sportovce se zdravotním postižením. Nicméně trenéři se zdravotním postižením, konkrétně basketbalu na vozíku a vozíčkářského ragby, se s tímto názorem neztotožňují. Nezastávají názor, že vlastní sportovní zkušenosti jsou při trénování tím rozhodujícím faktorem kvalitní trenérské práce (McMaster et al., 2012).

Dosavadní výzkum v oblasti sportovců se zdravotním postižením již dřive zdůraznil jednu zásadní skutečnost: trénovat a vnímat jedince se zdravotním postižením jako sportovce bez ohledu na jeho zdravotní postižení (DePauw \& Gavron, 2005; Cregan et al., 2007). Na základě výše uvedených specifik lze možná vycítit určitou názorovou rozporuplnost, ale ve skutečnosti tomu tak není. V rámci sportovního prostředí jedince se zdravotním postižením jednoduše vnímat především jako sportovce, nicméně akceptovat jeho zdravotní postižení v širším kontextu sportování. Výzkumné závěry relevantní studie jsou velmi nadějné. Účastníci studie, samotní trenéři, potvrdili změnu v kultuře vnímání sportovců se zdravotním postižením. V současné době trenéři vidí především sportovce, který má určité zdravotní postižení, než osobu se zdravotním postižením, která chce sportovat (Turnnidge et al., 2014).

\section{Trénování zdravotně postižených sportovců v praxi}

Zajímavá americká studie poukázala na skutečnost, že na Paralympijské hry v roce 1992 se pouze $58 \%$ z 319 amerických dospělých sportovců se zdravotním postižením připravovalo pod trenérským dohledem (Ferrara \& Buckley, 1996). Raději si nedovolme ani sebemenší spekulace, jak na tom v komparaci byly méně vyspělé nebo dokonce rozvojové státy. Každopádně v důsledku nedostatku kvalitního trenérství a nedostaku trenérů obecně je pochopitelné, že se mnozí sportovci se zdravotním postižením připravují nevhodným nebo nedostatečným způsobem. Negativní dopad této nekvalitní prŕípravy může ve výkonnostní rovině existovat $\mathrm{v}$ různých formách. Např́íklad v podobě přetrénování, tréninkové nedůslednosti, selhání na vrcholných akcích, nedostatku odpočinkového režimu, nevhodné životosprávy, organizačních problémů a v neposlední řadě i v neadekvátně stanovených sportovních cílech a v nevhodně sestavených tréninkových i soutěžních plánech (Martin \& Whalen, 2015). Z výše uvedeného textu jednoznačně vyplývá potřeba institutu trenérství. Výzkumné studie korespondující s tímto faktem dokonce označují roli trenérů sportovců se zdravotním postižením za velmi důležitou součást při získávání sportovních zkušeností v rámci sportovní etapy života (Martin, 2015; McMaster et al., 2012; Tawse et al., 2012). Nejdále však se svým tvrzením zachází studie, kde je trénování považováno dokonce za zlomový faktor ovlivňující sportovní výkon (Turnnidge et al., 2014). Trenérská kvalita poskytovaná zkušenými trenéry má jednoznačně velký vliv na sportovní úspěch (Martin \& Whalen, 2015; Turnnidge et al., 2014). Kromě zkušeností je pro trenéry nutné zvládnout i kritický mezilidský vztah trenér-sportovec (Turnnidge et al., 2014). Tento fakt dokladuje i hlavní 
zjištění studie plavců, kde velmi osobní a blízký vztah s trenérem měl v kontextu sportu pozitivní vliv na získané zkušenosti plavců se zdravotním postižením (Turnnidge et al., 2012).

Některé studie prezentují zásadní trenérský vliv u sportovců se zdravotním postižením na sportovní výkonnost prostřednictvím působení v oblasti psychické přípravy (Banack et al., 2011; Martin \& Whalen, 2015). Zejména se jedná o zvýšení sebevědomí a snížení obav ze selhání v souvislosti se sportovním výkonem. Také v další studii bylo jednoznačně prokázáno, že kvalitní a efektivní trénování pozitivně působí na sportovní výkonnost (Burkett \& Mellifont, 2008). Ačkoli výzkumy v oblasti zdravotně postižených sportovců jsou značně omezené, existuje dostatek podpory $\mathrm{k}$ dokumentaci dalších pozitivních či kvalitativně hodnotných výzkumných výsledků (Martin \& Whalen, 2015). Jedním z názorných př́kladů může být i situace, kdy trenér poskytuje svým svěřencům značnou autonomii, jež se pozitivně odráží na jejich silnější vazbě ke sportu a na pozitivních vztazích s ostatními spoluhráči. Dalším uvedeným př́kladem mohou být sportovci, kteří se cítili být podporováni v jisté nezávislosti. Vykazovali tím vyšší hodnoty vnitřní motivace v porovnání se sportovci, kteří vnímali své trenéry jako méně podporující ve své samostatnosti (Banack et al., 2011). V některých dalších výzkumech byla spokojenost $\mathrm{s}$ trénováním sportovců se zdravotním postižením také prokázána, nicméně se jednalo o lehce nadprůměrné hodnoty, konkrétně související s trénováním, s trenérskými pokyny a s osobním zacházením (Hatamleh et al., 2009). Autoři uvedených studií si také ověřili skutečnost, že pokud jsou sportovci se zdravotním postižením $\mathrm{k}$ trénování př́iznivě nakloněni, projevují v rámci tréninkového procesu větši spokojenost se získanými zkušenostmi, s osobním zacházením a se svými individuálními nebo týmovými výkony (Martin \& Whalen, 2015).

Hodnotné výsledky nemusejí být prezentovány pouze u vlivu na sportovní výkon nebo ve sportovním prostředí. Například u sportovců s poraněním míchy, kde pozitivních efektů bylo dosaženo i mimo sportovní oblast. Konkrétně lze v praxi dokumentovat studii basketbalistů na vozíku, speciálně sportovců se získaným zdravotním postižením. Trenérům se v této aktuální studii podařilo povzbudit, inspirovat a motivovat své svěřence k využivání nových příležitostí mimo sportovní sféru. Pro názornou ilustraci se jednalo o prohlubování jejich dalšího vzdělání, o odhodlání stát se více nezávislými, o uvědomění si možností vlastní kariéry, o větší zapojení v rámci dalších sportovních a rekreačních příležitostí, ale především o větší zainteresovanost v procesu trénování (Tawse et al., 2012). V rámci sportovních aktivit je dále potřeba přemýšlet i nad nepopulární stránkou sportu, a to zejména při zranění, u přerušení sportovních aktivit nebo při ukončení sportovní kariéry. I v této etapě by si trenéři měli uvědomit svůj vliv a pomoci sportovcům formou emocionální podpory v procesu odchodu do sportovního ústraní (Martin \& Whalen, 2015; Martin \& Wheeler, 2011). Na základě prezentovaných výzkumů lze konstatovat, že existují přesvědčivé důkazy o vlivu institutu trenérství na sportovce se zdravotním postižením nejenom na sportovním poli, ale i mimo sport.

Vrat'me se však na úplný začátek, respektive na úroveň obecné problematiky nebo příětivěji vyznívající obecné specifičnosti. Institut trenérství v kontextu sportovců se zdravotním postižením svou povahou spadá pod zastřešující a v této sféře značně použivané pojmy bariér a facilitátorů. Jedná se o skupinu specifikých problémů a okolností ve vztahu k tomuto minoritnímu okruhu sportovců, které komplikují nebo naopak ulehčují, každopádně však ovlivňují zapojení sportovních aktivit do životního stylu jedince se zdravotním postižením. Právě tyto okolnosti způsobují znatelnou disproporci a podstatně menší zainteresovanost do sportovních aktivit u této skupiny osob v komparaci se sportovní účastí zdravé části populace. Namátkou lze uvést data např́iklad z kanadského regionu, kde se uvádí poměr 1:10 (ParaSport Ontario, 2009) nebo anglického, který reprezentuje přivětivější poměr 1:3 (Sport England, 2002), tzn. na každých deset, respektive na každé tři zdravé sportovce připadne jeden sportovec se zdravotním postižením.

Takovéto bariéry sportovní účasti mohou nabývat různých forem. Nejčastěji se v této souvislosti objevuje dělení na externí a motivační, respektive na bariéry vztahující se k okolnímu prostředí a bariéry související s daným jedincem. Dostupnost sportovních zařízení, jejich bezbariérovost, informovanost, vstřícnost personálu, nabídka na rekreační úrovni, nedostatek financí a špatný př́stup k trenérovi na výkonnostní úrovni mohou být názornými př́klady bariér externího charakteru. $V$ případě motivačních bariér bývají nejčastěji skloňovány pojmy, jako je např́klad neefektivita, únava, nezájem 
nebo nulový vztah ke sportovním aktivitám. Jedná se vlastnosti, které mohou být např́íklad vyvolány doprovodným negativním efektem úrovně nebo typu zdravotního postižení. Dále nedostatkem víry ve vlastní schopnosti se realizovat nebo také traumatem $\mathrm{v}$ důsledku krizové události. Na základě těchto skutečností lze u této skupiny osob odvodit určité společenské limity, závisející na jejich fyzickém a psychickém stavu nebo jejich externím prostředí, které působí bud' jednotlivě nebo ve vzájemné kombinaci. V kontextu této problematiky ale existuje možnost, jak bojovat s omezením a jak převzít kontrolu nad svým životem. Jde o proces adaptace na nové sociální role ve společnosti. Stát se sebevědomím vůči novým výzvám, přetvořit svou sociální roli ve společnosti a stát se její novou součástí. Teprve potom budou mít jedinci, $\mathrm{v}$ rámci teorie sebeuplatnění reprezentující vztah $\mathrm{k}$ různým cílům a identitám, naději na úspěch, který závisí na interakci mezi jejich chováním, osobnostními činiteli a podmínkách daného prostředí (Albrecht \& Devlieger, 1999).

V kontextu pohybových aktivit výzkumy popisují specifickou identitu, tzv. sportovní identitu (Brewer et al., 1993; Sparkes, 1998), která je významným prediktorem nejenom pravidelné tělesné aktivity a sportovního chování $\mathrm{v}$ dlouhodobém horizontu, ale i schopnosti překonat nebo se vypořádat se samotnými bariérami sportovní účasti. Sportovní identitu můžeme charakterizovat jako specifickosportovní část multidimenzionální self-konceptu (Marsh, 2008), jež ovlivňuje do jaké míry se jedinec identifikuje do role sportovce (Brewer et al., 1993) a na jaké úrovni se př́ípadně bude sportovně angažovat (Lamont-Mills \& Christensen, 2006). Nebude asi př̌kvapením, že jsou popisovány tři druhy sportovní identity: a) nesportovec, b) budoucí sportovec a c) sportovec. Pro zajímavost lze uvést fakt, že u osob se získaným postižením vývoj sportovní identity pozitivně koresponduje s dobou po úraze. Sportovní identita se objevuje průměrně okolo páteho roku po dramatické události a zvyšuje se postupně s počtem uplynulých let (Burke, 2006; Perrier et al., 2014).

Vůbec největší bariérou se však zdají být negativní společenské stereotypy vůči zdravotně postiženým v běžném životě obecně, speciálně však v kontextu sportu. Přitom doba, kdy plná integrace do společnosti se realizovala pouze $\mathrm{v}$ případě absolutního vyléčení, je už dávnou a přežilou minulostí. Zastaralý lékařský model byl nahrazen sociálním modelem hendikepu, který klade větší důraz na kvalitu života, než na limitující faktory spojené se zdravotním stavem. V kontextu tohoto nového paradigmatu lze dosáhnout potřebného začlenění do společnosti prostřednictvím odstranění hendikepujících bariér. V závislosti na probíhajících debatách se v rámci všeobecné inkluze osob se zdravotním postižením, se opakovaně otevírá otázka hromadných sdělovacích prostředků (Sikorski \& Schierl, 2014). Ačkoliv jsou masmédia ve velké většině nositeli dominantních myšlenek a společenských norem, mohou na druhou stranu být iniciátory a zároveň projevem změn v kontextu těch, kteří jsou většinovou společností přehlíženi nebo utiskováni, jako je tomu např́iklad v př́ípadě sportu (Byusse et al., 2010). Nelson (1994) naprríklad konkrétně popisuje velkou moc a odpovědnost amerických masmédií v rámci zpravodajství, které mají př́íležitost $\mathrm{k}$ budování většího porozumění mezi majoritou a rozvíjejícími se menšinami. Vzhledem k jejich síle nelimituje dopad jenom na vnímání milionů Američanů, ale uvažuje o dopadu i v celosvětovém měř́tku.

Nedávné výzkumy v oblasti masmédií a jejich zpravodajských reportáží ve vztahu ke sportu osob se zdravotním postižením opětovně poukazují na významný fenomén v kontextu kvality a kvantity, který reflektuje všeobecnou mediální povahu zpravodajských reportáží osob se zdravotním postižením (Sikorski et al., 2012). Kromě těchto obecně známých skutečností je v rámci mediální viditelnosti sportovců se zdravotním postižením identifikována a souběžně analyzována negativní a stereotypní povaha reportáží, doprovázena negativním značkováním (Buysse \& Borcherding, 2010; Kama, 2004). Nepř́znivé označování může např́ilad přisuzovat a zdůrazňovat mizerný nebo bídný život související s postižením v závislosti na finanční a sociální podpoře. V kontextu sportu se pak zabývat otázkou sportovních schopností či sportovní kompetence zdravotně postižených sportovců (Buysse \& Borcherding, 2010) nebo v rámci sportovních reportáží opomíjet sportovní výkonnost a př́padně nereflektovat specifickou sportovní problematiku sportovců se zdravotním postižením (Sikorski \& Schierl, 2014). Záporně laděné značkování, které je často spojeno se sportovci s tělesným postižením, pomáhá uchovat negativní stereotypy. Opačného efektu lze také dosáhnout. Sportovec se zdravotním postižením byl př́ijemcem významně pozitivněji vnímán, když se charakter publikované zprávy za- 
měřil na specifické sportovní aspekty jako je výkonnost nebo soutěživost, na rozdíl od zpráv negativně vedených, např́klad v duchu závislosti nebo tragédie (Sikorski et al., 2012). Př́spěvek zachází ještě dále a dokazuje, že pokud bude potřeba vyvolat pozitivní hodnocení zobrazení sportovce se zdravotním postižením, bude po vizuální stránce plně dostačující, když sportovec se zdravotním postižením nebude vyobrazen pouze sám o sobě, ale $\mathrm{v}$ př́itomnosti menšího počtu diváků. Na počet divákủ lze v tomto prŕpadě uplatnit stropový efekt, respektive jejich zvyšováním se už efekt hodnocení nezlepší. Závěry této studie jasně deklarují důležitost vizuální komunikace v souvislosti se sportovními přenosy sportovců se zdravotním postižením a stejně tak důležitý potenciální vliv na př́ijemce, který se dostaví nezávisle na textovém obsahu (Sikorski et al., 2012).

Na základě současných výzkumů je možné identifikovat 3 hlavní podoby společenské prezentace zdravotního postižení, které jsou doposud reflektovány masmédii napříč celým světem. V kontextu sportu je lze demonstrovat na třech názorných př́kladech z filmového plátna (Gard \& Fitzgerald, 2008).

Ice Castles: poselstvím tohoto filmu je skutečnost, že i v př́padě nenadálé vady zraku se může člověk s tímto druhem postižením věnovat sportu. Nicméně obsahuje podtón zázračných počinů v souvislosti s vadou zraku a tímto kategoricky spadá pod pojem supercrip, jež je definován jako člověk, který překonal své postižení takovým způsobem, že může být považován za inspirativní (Berger, 2008).

Million Dollar Baby: vypráví o profesionální boxerce, jež se následkem úrazu v ringu stane kvadruplegičkou. Film působí pochmurně a depresivně, vzbuzuje otázku eutanázie, posiluje negativní vnímání člověka se zdravotním postižením ve stavu, kdy je lepší zemřít, než s postižením žít.

Murderball: film edukativního charakteru, s prvky kontroverze, je pohledem do života sportovců hrajících vozičkářské ragby. Autoři recenze se shodují v tom, že tvůrci filmu se snažili vykreslit člověka se zdravotním postižením na docela běžných ideálech v podobě hezkého, svalnatého a sexuálně aktivního, tedy stejně jako zdravého člověka, stereotypního hypermaskulinního vzoru.

Podobně současný problém vnímá i ojedinělý prŕíspěvek z české produkce. Tejkalová (2008) se ve své mediálně zaměřené studii v kontextu sportovců se zdravotním postižením zmiňuje "o těch druhých" jako o hrdinech, př́padně reflektuje koncept stereotypizace a jinakosti (Hall, 2001; Pickering, 2001). V dalších studiích jsou osoby se zdravotním postižením v běžném životě nejčastěji značkováni v téměř shodném stylu, respektive jako oběti nebo hrdinové (Block, 2007; Gard \& Fitzgerald, 2008) s tím, že u hrdinů je připojena konkrétní oblast výskytu, a to především v kontextu sportu, byznysu nebo vztahu (Block, 2007). V současné době s vysokou pravděpodobností neexistuje jasný názor, kterým směrem by se propagace sportovců se zdravotním postižením měla ubírat (Cottingham et al., 2013). Je ale pravdou, že studie zahrnující samotné názory sportovců, kteří byli označeni nálepkou supercrip, měli vůči tomuto označení své výhrady (Hargreaves \& Hardin, 2009). V kontextu této problematiky je nutné zmínit i názor, že označení supercrip nemusí znamenat nic jiného, než negativní označení jedinců, kterým se dař́ žít svůj „obyčejný“ život (Kama, 2004).

V této souvislosti je sport osob se zdravotním postižením považován za slibnou komunikační linii medializace osob se zdravotním postižením pro svou stimulaci společensky žádoucích hodnot (Sikorski \& Schierl, 2014). Sport osob se zdravotním postižením již dlouhou dobu není pouze součástí rehabilitace nebo volnočasovým doplňkem. Orientace osob se zdravotním postižením na soutěžní stránku sportu způsobila nárůst počtu zájemců o sport obecně a spolu s popularitou paralympijských soutěží pozvedla výkonnostní i soutěžní úroveň sportu jako takového (Falcão et al., 2015). Symbol sportu a sportovců se zdravotním postižením v podobě Paralympijských her se řadí mezi největší sportovní události ve světě, kde zaujímá druhou pozici hned po Olympijských hrách (International Paralympic Committee, 2015). Je to dáno nejen počtem účastníků, ale i svým významným vlivem na rozvoj paralympijských sportů. Především kvůli samotným paralympionikům, jako slibnému komunikačnímu nástroji z pohledu společensky pozitivního vnímání osob se zdravotním postižením, nikoliv však pro své limity a omezení, ale hlavně pro jejich fyzickou zdatnost a výkonnost (Sikorski et al., 2012). V širším společenském kontextu se přidává i př́spěvek, který vidí hlavní úlohu Paralympijských her ve změnách postojů vůči postižení obecně, ve zrychlování programu 
inkluze a v prosazování bezbariérového konceptu životního prostředí (Gold \& Gold, 2007). Pokud teoreticky dojde k mediálnímu obrazu sportovců se zdravotním postižením, který bude kompatibilní se společensky uznávaným konceptem sportu, respektive $\mathrm{v}$ podobě tří překrývajících se představ o fyzické zdatnosti, svalnatosti a sexualitě (DePauw, 1997), nemuseli by být paralympijští sportovci masmédii považováni za nekompetentní a paralympijský sport za nelegitimní sportovní záležitost (Buysse \& Borcherding, 2010).

\section{Závěrem}

Sport je universální fenomén s obrovskou mocí. Tento fakt platí bez výjimky i pro oblast sportu osob se zdravotním postižením. Slova bývalého boxera Nelsona Mandely to mohou jen potvrdit. Sport pojmenoval nejúčinějším prostředkem komunikace moderního světa a posunul nad rámec komunikace verbální a psané (Maguire, 2005). Sport z určité perspektivy spojuje národy, spojuje generace a především spojuje nás všechny. Myšlenka, že právě sport může v současné době sehrát obrovskou roli ve všech pádech skloňované inkluzi, není daleko od věci. Sportovci se zdravotním postižením si svými výkony řekli o vnímání sebe samých především jako sportovců a stali se uznávanou a oprávněnou součástí sportovního světa. Sport se díky tomu může stát silným nástrojem k nastavení nového paradigmatu, ne však stereotypně značkovaných zdravotně postižených, ale spíše ,zdravě postižených“ sportovců, neboli sportovců postiženým sportem stejně, jako v prípadě běžně vnímaných sportovců. Transcendentní charakter sportu může sehrát jednu ze zásadních rolí ve smyslu odstranění bariér ve většinové společnosti. V celospolečenské rovině by měl být sport v pozici veřejného zájmu, nebot' podpora sportu v moderní společnosti působí nejenom jako integrační prvek, ale především jako významný faktor ochrany veřejného zdraví s pozitivním dopadem na výlohy související se zdravotní péčí. Provozováním sportu se plně využívají jeho možnosti v podobě zdravého životního stylu a zlepšení kvality života, obzvláště pak u „těch druhých”.

\section{Literatura}

Albrecht, G. L., \& Devlieger, P. J. (1999). The disability paradox: High quality of life against all odds'. Social Science \& Medicine, 48, 977-988.

Banack, H. R., Sabiston, C. M., \& Bloom, G. A. (2011). Coach autonomy support, basic need satisfaction, and intrinsic motivation of paralympic athletes. Research Quarterly for Exercise \& Sport, 82(4), 722-730.

Berger, R. J. (2008). Disability and the dedicated wheelchair athlete beyond the "Supercrip" critique. Journal of Contemporary Ethnography, 37(6), 647-678.

Block, M. E. (2007). A teacher's guide to including students with disabilities in general physical education (3rd ed.). Baltimore, MD: Paul H. Brooks Publishing Co.

Brewer, B. W., Van Raalte, J. L., \& Linder, D. E. (1993). Athletic identity: Hercules' muscles or Achilles' heel? International Journal of Sport Psychology, 24, 237-254.

Burke, P. J. (2006). Identity change. Social Psychology Quarterly, 69(1), 81-96.

Burkett, B., \& Mellifont, R. (2008). Sport science and coaching in Paralympic swimming. International Journal of Sports Science and Coaching, 3(1), 105-112.

Buysse, J. A. M., \& Borcherding, B. (2010). Framing gender and disability: A cross-cultural analysis of photographs from the 2008 Paralympic Games. International Journal of Sport Communication, 3(3), 308-321.

Clarke, K. S. (1986). Perspectives for the future of the disabled in sport. Adapted Physical Activity Quarterly, 3, 152-155.

Cottingham, M., Byon, K. K., Chatfield, C., \& Carroll, M. (2013). Examining the influences of relationship to disability on wheelchair basketball spectators. Disability Studies Quarterly, 33(3), 19-19.

Crawford, J. L., \& Stodolska, M. (2008). Constraints experienced by elite athletes with disabilities in Kenya, with implications for the development of a new hierarchical model of constraints at the societal level. Journal of Leisure Research, 40(1), 128.

Cregan, K., Bloom, G. A., \& Reid, G. (2007). Career evolution \& knowledge of elite coaches of swimmers with a physical disability. Research Quarterly for Exercise \& Sport, 78(4), 339-350.

DePauw, K. P. \& Gavron, S. J. (2005). Disability \& sport (2nd ed.). Champaign, IL: Human Kinetics.

DePauw, K. P. (1986). Research on sport for athletes with disabilities. Adapted Physical Activity Quarterly, 3(4), $292-299$.

DePauw, K. P. (1997). The (in) visibility of disability: Cultural contexts and "sporting bodies". Quest, 49(4), 416-430. 
Falcão, W. R., Bloom, G. A., \& Loughead, T. M. (2015). Coaches' perceptions of team cohesion in paralympic sports. Adapted Physical Activity Quarterly, 32, 206-222.

Ferrara, M. S., \& Buckley, W. E. (1996). Athletes with disabilities injury registry. Adapted Physical Activity Quarterly, 13, 50-60.

Gard, M., \& Fitzgerald, H. (2008). Tackling Murderball: Masculinity, disability and the big screen. Sports Ethics and Philosophy, 2(2), 126-141.

Gold, J. R., \& Gold, M. M. (2007). Access for all: The rise of the Paralympic Games. The Journal of the Royal Society for the promotion of Health, 127(3), 133-141.

Hall, S. (2001). The Spectacle of the Other'. In S. Hall (ed.). Representation. Cultural representations and signifying practices, 224-279. Thousand Oaks, CA: Sage

Hanrahan, S. J. (2007). Athletes with disabilities. In: G. Tenenbaum \& R. C. Eklund (Eds.), Handbook of sport psychology (3rd ed.), 845-858. Hoboken, NJ: John Wiley.

Hargreaves, J., \& Hardin, B. (2009). Women wheelchair athletes: Competing against media stereotypes. Disability Studies Quarterly, 29(2), 7-7.

Hatamleh, M. R., Al-Ruz, H. H. A., \& Hindawi, O. S. (2009). Coach's leadership behavior as a predictor of satisfaction with leadership: Perceptions of athletes with physical disabilities. International Journal of Applied Educational Studies, 4(1), $14-33$.

Horn, T. S. (2008). Coaching effectiveness in the sport domain. In T. S. Horn (Ed.), Advances in sport psychology (3rd ed.). Champaign, IL: Human Kinetics.

International Paralympic Committee (2015). The IPC - Who we are/History of the movement. Retrieved 10.9.2015 from the World Wide Web: http://www.paralympic.org/the-ipc/history-of-the-movement

Kama, A. (2004). Supercrips versus the pitiful handicapped: Reception of disabling images by disabled audience members. Communications: The European Journal Of Communication Research, 29(4), 447-466.

Kawanishi, C. Y., \& Greguol, M. (2013). Physical activity, quality of life, and functional autonomy of adults with spinal cord injuries. Adapted Physical Activity Quarterly, 30(4), 317-337.

Lamont-Mills, A., \& Christensen, S. (2006). Athletic identity and its relationship to sport participation levels. Journal of Science and Medicine in Sport, 9(6), 472-478.

Lee, J. \& Porretta, D. (2013). Document analysis of sports literature for individuals with disabilities. Perceptual \& Motor Skills, 116(3), 847-858.

Maguire, J. A. (2005). Power and global sport: Zones of prestige, emulation and resistance. London, UK: Routledge.

Marsh, H. W. (2008). A multidimensional, hierarchical model of self-concept: An important face of personality. In G. J. Boyle, G. Matthews, \& D. H. Saklofske (Eds.), The Sage handbook of personality theory and assessment, vol. 1: Personality theories and models, 447-469. Thousand Oaks, CA: Sage.

Martin, J. J. (2015). Determinants of Elite Disability Sport Performance. Kinesiology Review, 4(1), 91-98.

Martin, J. J., \& Whalen, L. (2015). Effective practices of coaching disability sport. European Journal of Adapted Physical Activity, 7(2), 13-23.

Martin, J. J., \& Wheeler, G. (2011). Psychology. In Y. C. Vanlandewijck \& W. R. Thompson (Eds.), The Paralympic athlete: Handbook of sports medicine and science. Oxford, United Kingdom: Wiley-Blackwell.

McMaster, S., Culver, D., \& Werthner, P. (2012). Coaches of athletes with a physical disability: A look at their learning experiences. Qualitative Research in Sport, Exercise \& Health, 4(2), 226-243.

Meyers, A. R., Anderson, J. J., Miller, D. R., Shipp, K., \& Hoenig, H. (2002). Barriers, facilitators, and access for wheelchair users: Substantive and methodologic lessons from a pilot study of environmental effects. Social Science \& Medicine, 55(8), 1435-1446.

Nelson, J.A. (1994). Broken images: Portrayals of those with disabilities in American media. In J.A. Nelson (Ed.), The disabled, the media, and the information age, 1-17. Westport, CT: Greenwood Press.

ParaSport Ontario (2009). Parasport Ontario resource directory. Toronto, ON: Author.

Perrier, M. J., Smith, B., Strachan, S. M., \& Latimer, A. E. (2014). Narratives of athletic identity after acquiring a permanent physical disability. Adapted Physical Activity Quarterly, 31(2), 106-124.

Pickering, M. (2001). Stereotyping: The politics of representation. New York, NY: Palgrave Macmillan.

Rimmer, J. H., Riley, B., Wang, E., Rauworth, A., \& Jurkowski, J. (2004). Physical activity participation among persons with disabilities: Barriers and facilitators. American journal of preventive medicine, 26(5), 419-425.

Robbins, J. E., Houston, E., \& Dummer, G. M. (2010). Philosophies \& expectations of wheelchair \& stand-up collegiate basketball coaches. Journal of Sport Behaviour, 33(1), 42-62.

Sawicki, O. (2008). Reflections on the 2008 Beijing summer paralympic games - a canadian paralympic committee perspective. Coaches Plan, 15(3), 37-39.

Sikorski, C. V., \& Schierl, T. (2014). Inclusion of persons with disabilities through media sports: Attitudinal and behavioral news-framing effects. International Journal of Sport Communication, 7(1), 90-112.

Sikorski, C., Schierl, T., Möller, C., \& Oberhäuser, K. P. (2012). Visual news framing and effects on recipients' attitudes toward athletes with physical disabilities. International Journal of Sport Communication, 5(1), 69-86.

Sparkes, A. C. (1998). Athletic identity: An Achilles' heel to the survival of self. Qualitative Health Research, 8, 644-664. 
Sport England (2002). Adults with a disability and sport national survey 2000-2001. Headline findings. London, UK: Author. Tawse, H., Bloom, G. A., Sabiston, C. M., \& Reid, G. (2012). The role of coaches of wheelchair rugby in the development of athletes with a spinal cord injury. Qualitative Research in Sport, Exercise \& Health, 4(2), 206-225.

Tejkalová, A. (2008). Mediální reprezentace českých handicapovaných sportovců. Edice pracovních sešitů PSSS. Praha: FSV UK. Turnnidge, J., Côté, J., Hollenstein, T., \& Deakin, J. (2014). A direct observation of the dynamic content \& structure of coach-athlete interactions in a model sport program. Journal of Applied Sport Psychology, 26(2), 225-240.

Turnnidge, J., Vierimaa, M., \& Côté, J. (2012). An in-depth investigation of a model sport program for athletes with a physical disability. Psychology, 3(12), 1131-1141.

van der Ploeg, H. P., van der Beek, A. J., van der Woude, L. H., \& van Mechelen, W. (2004). Physical activity for people with a disability. Sports Medicine, 34(10), 639-649.

Wilson, N. C., \& Khoo, S. (2013). Benefits and barriers to sports participation for athletes with disabilities: The case of Malaysia. Disability \& Society, 28, 1132-1145.

World Health Organization (2011). World Report on Disability. Retrieved 7.7.2014 from the World Wide Web: http://www. who.int/disabilities/world_report/2011/report/en/

Wynnyk, K., \& Spencer-Cavaliere, N. (2013). Children's social relationships \& motivation in sledge hockey. Adapted Physical Activity Quarterly, 30(4), 299-316.

\section{Corresponding author}

Ing. Tomáš Zelenka, Univerzita Palackého, Olomouc, Česká republika tomas.zelenka@volny.cz 